\title{
Can the Horn Change?
}

\author{
Christopher Clapham \\ University of Cambridge, Cambridge, UK
}

\begin{abstract}
The Horn of Africa constitutes a distinct region within the African continent, historically characterized by exceptionally high levels of conflict, with resulting humanitarian disasters. Recent developments, especially in the core state of Ethiopia, raise the possibility of transforming it into a more peaceful and collaborative part of the world, even though this is threatened by governance failures in Eritrea and state collapse in both Somalia and South Sudan. Relations between regional states are now more cooperative than at any previous period, and though intractable problems remain, notably in Somalia and South Sudan, there is at least a prospect that, with skilful management, this historically troubled part of Africa may be able to escape from the legacies of its past.
\end{abstract}

Keywords: Eritrea, Ethiopia, Horn of Africa, political transformation, Somalia

\section{Introduction}

The Horn of Africa — comprising the states of Djibouti, Eritrea, Ethiopia, Somalia and Somalil and — forms a distinctive part of the continent, seemingly immune to many of the patterns of change that have affected the rest of Africa - and indeed the world - over the last century and more. Only very partially subject to the unifying logics of European colonialism, not just in Ethiopia but also in the Somali territories formally colonized by Italy and the United Kingdom, it has been driven far more by the internal dynamics of its own domestic populations, societies and political structures than by models of statehood and development imposed from outside. Symptomatically, it has also fostered a specialist cadre of scholars, drawn to the region by a fascination with its peculiar character and history, and to a large extent (Donham \& James, 1986; pp. 246-249, Feyissa \& Hoehne, 2010) isolated from their colleagues studying other parts of Africa and the developing world.

In this context, it may be worth raising two linked and apparently simple questions. First, at the level of the actual politics of the Horn and the societies on which it rests, is there any plausible prospect of transformation - that is to say, of converting a region historically identified with poverty and conflict, into something different, more closely corresponding to patterns of development elsewhere in the world, and notably more capable of creating lives for its citizens less desperate than those that they have all too often had to suffer in the past, and continue to suffer in the present? Or conversely, is this part of the world so locked into specific historical legacies, so path dependent in its social patterns, its ways of looking at the world, and its place in the global order, that all we can plausibly project for it is the mixture as before-maybe altered in detail, adapted to new circumstances, expressed in new language, but basically the same as that with which we are already all too familiar?

Christopher Clapham, Professor, Centre of African Studies, University of Cambridge. 
Second, at the level of the academic understanding of the Horn, are specialist scholars similarly locked into specific ways of looking at it? Do the dominant narratives that have tended to shape their approaches to it follow on from, and in the process reinforce, an essentially historicist vision, and at the same time privilege their own expertise, derived from long experience of the region, and familiarity with its peculiar histories and societies? And do specialists in the region, as a result, become prisoners of their own mentalities, incapable of viewing the region in any other way from that to which we have become accustomed, and in the process miss critical factors of change?

These are very large questions to raise in a brief discussion paper, but ones that are worth asking, not least in the context of apparent changes in the region, which may offer the possibility of escape from its often bitterly remembered past, and often evidently unsustainable present, into a rather more promising future. These are not questions to which this essay will be able to provide definitive answers, but it is nonetheless important to keep looking for options, expanding the available ideas of the possible, and asking whether long-held assumptions still hold true.

At one level, certainly, the Horn has changed dramatically over the past half-century, and continues to do so. On my first visit to the region, in 1962, I was able to travel by ordinary public bus from Kassala in the Sudan, across the frontier to Tessenei in an Eritrea then still federated with Ethiopia, to Agordat, Keren and Asmara, and then down the escarpment to Massawa and across to the magical Dahlac islands, where I was going to watch birds (Clapham, 1964). Apart from the standard checking of my papers at the border post in Tessenei, there were no checks, no road blocks, no visible signs of the military, or anything else to disturb the impression of a country at peace. Only a few years later, as the insurgency in Eritrea (which is conventionally regarded as having started in 1961, but of which I saw and heard no sign in 1962) gathered pace, such a journey became impossible, and at few if any times over the succeeding years, even after the independence of Eritrea in 1991, could it have been replicated. It is a very simple indicator, at a personal level, of what has been lost. By the present time, even someone familiar with Addis Ababa during the 1960s would often be completely disoriented, given the massive clearances and rebuilding that has taken place in recent years, and even the massive bulk of Wachacha, the great mountain to the west on which the sun used set over the city through the crystal-clear highland air, is almost obscured by the smog of brown exhaust fumes.

This is indeed a region which, over that half-century, has witnessed some of the most traumatic events, not only in Africa but in the entire world, events that can have left no one in the region unaffected, and that have caused massive numbers of deaths, and left deep scars on the survivors. The Ethiopian revolution of 1974 is comparable in the modern era only to those in China and Indochina, and bears unmistakable resemblances to the "great revolutions" in France at the end of the eighteenth century, and Russia at the start of the twentieth. Like them, it was accompanied by a reign of terror in which rival revolutionary factions fought one another to the death, and by wars both internal and external as both the country itself and the wider world became embroiled in the upheavals that it had unleashed. The struggle for independence in Eritrea likewise has no real equivalent beyond Indochina. The Horn has equally witnessed the world's most complete example of state collapse in Somalia, to which South Sudan may now tragically have to be added, and Africa's only three cases of state division: the separation of Eritrea from Ethiopia, of Somaliland from Somalia, and of South Sudan from Sudan. Accompanying all these changes have been humanitarian disasters, notably famine and refugee movements, on an epic scale. 
In this context, to talk of continuities and path dependencies may seem ridiculous, and yet when I returned to now revolutionary Ethiopia, after a long absence, in 1984, expecting to see everything totally transformed from old 'feudal' Ethiopia, I was struck not only by what had changed, but by what remained the same, and especially by the extent to which people still thought the same (Clapham, 1988). The continuities of the Horn are most deeply entrenched in the always fascinating and frequently bizarre mentalities of its peoples. Reading René Lefort's $(2007,2010,2012)$ wonderful accounts of the impact of the EPRDF on Amhara peasant societies in north Shoa is to be constantly reminded that these are precisely the same people whom Don Levine (1965) studied 50 years earlier. "We are people to be ordered", as Lefort's informants told him (Lefort, 2012, p. 687). Levine's informants were no less aware of their subjection to a hierarchy that they could do nothing to change. One is left feeling that 50 years of trauma have made no difference to them at all. Nor indeed are Amhara peasants unique in this respect: research among Somali pastoralists reveals a similar continuity, albeit of very different attitudes. If structural transformation is to be achieved in the Horn, it may be too much to expect that such mentalities should change, but it would at least be necessary to make them fit into very different settings.

\section{The Centrality of Ethiopia}

Any search for possible sources of transformation must start in Ethiopia, simply because the inescapable centrality of Ethiopia to the entire region gives it an importance that no other part of the Horn can match. Ethiopia is easily the largest state in the region, in terms alike of territory, population, economy and military power. It has frontiers with every other regional state, and the relations that each of those states has with Ethiopia are critical to its own development, and to its prospects for peace and security. It likewise enjoys a privileged position in mediating the region's relationships with the rest of the world, both in Africa and beyond. Ethiopia's power and its problems project themselves across its frontiers, with the result that fundamental change in the region is impossible unless it happens in Ethiopia.

The basic narrative of Ethiopia, to which every attempt to understand it eventually returns, is that of the "state": its age, its size, its embeddedness in specific parts of the national territory and its imposition on others, the attitudes to authority that have historically sustained it, and the relations of hierarchy, dominance, control, and often sheer brutality that have been associated with it. The lesson of the last 50 years has been that attempts to transform that state, however massive the upheavals that these have brought about, have, once the dust has cleared, revealed the Ethiopian state, transformed indeed in some ways, but nonetheless recognisably the same, and indeed in critical respects even stronger than before.

The Derg state which emerged from the 1974 revolution, like the Jacobin state in France after 1789, or the Soviet state after 1917, essentially swept away the pre-revolutionary obstacles to state power, and built a still more ruthless, more hierarchical, more militarized and more predatory state than that which had previously existed, albeit one that was now, in principle at least, constructed on the basis of nationalism, citizenship and equality, in place of the historic imperial hierarchy that it displaced. Much more intriguing, because in principle it ran directly counter to previous conceptions of statehood, has been to watch the reconstitution of the Ethiopian state by the Ethiopian Peoples' Revolutionary Democratic Front (EPRDF) which seized power in 1991, behind the façade of federalism, including the formal provision that Ethiopia is no more than the voluntary association of the 'nations, nationalities and peoples' that comprise it, each of which enjoys a right of "self-determination up to and including secession", explicitly recognized in its constitution (FDRE, 1994, Arts. $8,39)$. 
Whereas 24 years ago, when the EPRDF first came to power, the language of Ethiopian politics was overwhelmed by the issue of "nationalities", this now appears to have been significantly reduced. Federalism currently figures most prominently as a constitutional formula for distributing major posts in government (such as those of the prime minister and deputy prime ministers) between the four major regions-Tigray, Amhara, Oromiya, and the Southern Nations - that emerged from the federal reconstruction of the country's internal administrative units. In the process, a project that initially appeared to be bent on dismantling the Ethiopian state has instead seen it revived, with the 1998-2000 war against Eritrea, and the 2005 elections, as critical points along the way. The first of these events, including notably the massive and apparently country-wide reaction triggered by the forcible Eritrean occupation of a small strip of contested territory along the country's northern frontier, essentially reconstituted the idea of Ethiopian nationalism. The second, with the incumbent regime's brutal suppression of opposition forces (of which the most important element, the Coalition for Unity and Democracy (CUD), was broadly nationalist rather than regionalist in orientation), correspondingly re-established the primacy of centralized authoritarianism (Crisis Group, 2009; Gilkes, 2015).

So, far from challenging the dominant narratives of Ethiopian statehood through which observers have become accustomed to trying to understand the country's political structure and trajectory, the EPRDF experience appears to have left these narratives at least as prominent as before. Indeed, one could plausibly argue that they are now even less challenged than they were, either by the student revolutionaries of the 1960s and 1970s who contested the essential "meaning" of Ethiopia against the imperial regime, or subsequently by the regional insurgencies of the late 1970s and 1980s which likewise contested that meaning against the revolutionary militarized centralism of the Derg. By formally embracing and co-opting (far more in principle than in practice) the forces both of revolutionary socialism and of separatist ethnic nationalism, the EPRDF appears for the moment at least to have neutralized them both. Because of its very nature, the Ethiopian state necessarily faces structural challenges, whether these be from Islam or from religion and civil society more generally, or else from separatist nationalisms among which that of the Oromo is by far the most significant; but the prospect of transforming the entire political geography of the region by splitting Ethiopia into a collection of ethno-states now appears to be remote. The successful separation of Eritrea rested both on a political and territorial formula (that of a post-colonial territoriality akin to formerly colonial states throughout the African continent), and on a politico-military structure (the extraordinarily powerful and effective Eritrean People's Liberation Front or EPLF), that have not been (and in the case of the first, cannot be) replicated elsewhere in Ethiopia. So far from being the prologue to a general process of territorial dismemberment, Eritrean independence looks more than ever like a one-off event.

There is now, moreover, a new narrative of transformation emerging in Ethiopia, ostensibly less threatening to existing structures of statehood than either revolutionary socialism or ethnic federalism, and indeed founded on those structures and seeking to reinforce them. This is the narrative of Ethiopia as a developmental state, which has the state at its core, and derives from external models, principally those of the People's Republic of China and in some degree South Korea, that place very heavy emphasis on the role of the state in promoting, guiding and regulating the process of economic development. But however far these models may be from laissez-faire liberalism, they are at the same time tied to the role of markets, both domestic and international, and seek to foster means of production explicitly geared to mobilizing sources of comparative advantage within the global economy. Regardless of the precise figures, economic growth in Ethiopia over the last 10 or 15 years has been dramatic, not only in Addis Ababa where it is most visible, or even just in towns, 
but way out into the countryside, and constitutes the major source of potential transformation in the Horn as a whole. Especially impressive has been the growth of the road network and other infrastructural projects, together with health and education, and a capacity for hydroelectricity generation that is still underway, notably in the form of the Grand Ethiopian Renaissance Dam (GERD), currently being constructed on the Abbay (Blue Nile) river, close to the Sudanese border, with further dams already built on the Gibe river in southern Ethiopia.

It has to be recognized that developmental statehood has had a very uneven impact on the overall process of development in Ethiopia. Those elements in the process that can be directed in thoroughly Ethiopian fashion from the top downwards, like roads and education systems, figure much more prominently than those that have to be built from the bottom up, like entrepreneurship, civil society, and relations of trust between groups and individuals. Though the evidence of physical change, especially in infrastructure, is massive, Ethiopia lags in terms of indicators that depend on private entrepreneurship, and the ability of enterprising individuals to prosper independently of the heavy hand of central regulation. Mobile telephone penetration, for example - the technology that more than any other has driven economic growth in Africa in recent years-at 32 subscribers per 100 people, is the sixth lowest in Africa (World Bank website1), a serious deficiency that derives from the state's insistence on maintaining control over telecoms, and the consequent absence of the free market in telephony that is such a feature, for example, of Kenya with 74 subscribers per 100 people (Gagliarodone, forthcoming). The percentage of the population with access to personal bank accounts is similarly low (World Bank website 2) - and unsurprisingly so, given the state's insistence that a percentage of deposits must be held in government bonds which amount to a forced loan to the government at punitively negative rates of interest. A telephonic money transfer system like M-pesa in Kenya is not currently feasible in Ethiopia. The early achievements of Ethiopian state-directed development, must therefore-sooner rather than later-face the challenges created by its problems in coming to terms with the market, which may eventually subvert the state-centered system that it has initially strengthened.

Indeed, even though state-society relations in Ethiopia continue to be driven heavily by the state, there is sufficient evidence of deep-seated changes at the level of society to suggest that this priority may be reversed. In Ethiopia, as in other parts of Africa, social change beyond the purview of the state is most strikingly revealed by the range and intensity of new religious movements. Even though changes in Islam have often attracted the greatest attention (Ficquet, 2015; Østebø \& Desplat, 2013) — understandably enough, given their global scope and the challenge that they pose to Western interests and to the diffusion of modernist concepts of development - the extraordinarily rapid growth of protestant and especially evangelical Christianity is every bit as significant. This now constitutes the third major element in Ethiopia's religious life, after Orthodoxy and Islam, and is concentrated in the socially and economically most dynamic areas of the country, the non-Amhara centre and south-west, inhabited by the Oromo and southern peoples (Fantini, 2015). Already by 2007 Ethiopian protestants were officially recognized as amounting to nearly 14 million people (FDRE, 2008) or $18.6 \%$ of the national population, most of them belonging to the Kale Heywet and Mekane Yesus churches, and the numbers are likely to have grown significantly since then. This brings at least the possibility of changes in underlying social attitudes far more subversive of historic structures of statehood than Marxism-Leninism, and it is here more than anywhere else that - from a Weberian perspective - basic attitudes and ways of thinking may be changing, and further studies that explore the impact of religious change on social attitudes, political behavior, and economic development are now urgently needed. 
This too is a change that has to some degree been incorporated into the political structure, with the peaceful succession after the death of Meles Zenawi in 2012 of a national leader who is not only from the deep south-Welayta - but is also a protestant Christian. The appointment of Hailemariam Desalegn as prime minister by the EPRDF is also astonishing for a post-liberation regime in that he comes from entirely outside the "struggle", which in almost every such regime - from Cuba through post-apartheid South Africa to Chinacontinues to define leadership qualifications far into the future. The absence of liberation credentials is obviously in some respects an indicator of weakness, and control of the security sector remains in the hands of veterans of the struggle. Issues of political succession in Ethiopia have historically been resolved only with the eventual emergence of a strongman, and anything in the nature of a collegiate leadership has been short-lived. The shift from military prowess to developmental expertise as the basis for national leadership is nonetheless intriguing.

Whereas changes in religious narratives in Ethiopia have been very marked, I have failed to detect any equivalent change in narratives of ethnic identity, by far the most important of which is that of the Oromo. The first significant attempt to construct such a narrative, Mohammed Hassen's The Oromo of Ethiopia (1990), placed a heavy emphasis on the ability of the Oromo to create states, illuminated in particular by those of the Gibe region. Given a context in which states could be regarded as essential in order to project a viable project of nationhood, this was perfectly understandable. With the publication of Being and Becoming Oromo (Baxter, Hultin \& Triulzi, 1996), however, the focus shifted to a search for social characteristics that distinguished Oromo from the state-centric peoples to the north, and in particular to the articulation of the historic age-grade system, gada, as emblematic of an identity constructed from the bottom up, and to a conception of Oromoness as encompassing inclusive and democratic ideals at variance from Ethiopian authoritarianism. There the issue rests, and no more recent attempt appears to have been made to use this vision to address specific issues in the politics and identities of particular Oromo societies, extending as these do across a very wide range of beliefs and practices - from the Islam of much of eastern and southern Oromia to the protestant Christian societies of the west. Essentially, the quest for an Oromo narrative rests on the need to identify a specific modern setting within which it can be anchored.

\section{The Eritrean Tragedy}

But if the central narrative of Ethiopia is the state, that of Eritrea is clearly the struggle - the long, bitter, costly and eventually triumphal conflict through which Eritrea under the leadership of the EPLF fought for and attained independence from Ethiopia - and this is a narrative now even more due for challenge, and indeed for change, than the Ethiopian fixation with statehood. Somalia is often unfairly described as a "failed state", whereas in fact it is not a state at all and never has been: the idea of statehood in Somalia has amounted to little more than an attempt to devise something that might be recognized as a state by the outside world, and with which the rest of the world could therefore plausibly do business, regardless of how meaningless this was to most of the people who comprised it. The "real" failed state of the region is Eritrea, which is unquestionably a state but one that has utterly failed to provide its people with the public goods that a state exists to provide. The "sacrificial citizenship" that Victoria Bernal (2013) has described is correspondingly incapable of providing the basis for any sustainable relationship between Eritreans and the mechanisms through which they are governed, as is dramatically indicated by a level of refugee flight, which with a staggering 416,857 refugees and asylum seekers that in proportion to a population variously estimated at between four and nearly seven 
million exceeds any in the world, beyond zones of intense and immediate conflict (UNHCR website; Eritrea website).

On the one hand, obviously enough, Eritreans' long and heroic fight for independence is so critical, both to the creation of any sense of national identity, and to the mentalities of the governing elite, that it seems redundant to look for any other lens through which to examine and explain the country's post-independence trajectory. Indeed, even the refugees who have risked (and often lost) their lives seeking to flee Eritrea appear to share, to a remarkable degree, the national narratives of the country from which they have escaped (Kibreab, 2013). On the other hand, however, the gulf between the aspirations that so many Eritreans fought and died for, and the fate to which they have since been subjected, is now so gross - and heart-breaking - that it has become essential to look for new narratives of Eritreanness to replace the now bankrupt legacy of struggle. There is a danger, indeed, that a constant harking backwards to the origins of Eritrea's national mythology may serve, however unwittingly, to condone the way in which power has been used and abused since independence by those who have appropriated that mythology for their own use.

In this context, it is salutary to remember that generational change in Africa is very fast. Time and demography now dictate that only Eritreans over the age of 35 years old - certainly a minority of the total population - have any usable memory of the struggle for independence to draw on, a proportion that diminishes steadily year-on-year. That this memory is now quite insufficient to sustain any commitment to the state that the struggle created is testified by the huge number of Eritreans who have fled abroad, exposing themselves to terrible dangers in the process. Ostensible commitment to official narratives in the Horn, moreover, is often no more than a façade, no matter how convincingly these may be presented. During July and August 2001 for example, after a group of fifteen leading members of the regime had made their short-lived gesture of defiance against Isayas Afwerki, but before they had been rounded up and brutally imprisoned, the monolithic façade of Eritrean unity briefly cracked, and one could conduct meaningful conversations with Eritreans within Eritrea-both those who continued to support the regime, and those who were prepared to express their misgivings about it - in a way that had not been possible before, and became impossible again all too soon afterwards. What was striking about this experience was the discovery of how much Eritreans continued to think about their country's predicament, all too sharply revealed by the catastrophic war of 1998-2000, and to search for ways in which it might be able to develop into a "normal" state, capable of achieving the aspirations of its people. The tragedy of the September 2001 clampdown is that any such quest was stifled.

It would be hazardous to attempt to predict where the new Eritrea is going to come from, but it may at least be possible to indicate some of the parameters that will go to shape the process. The first is that any possibility of 'reunion' with Ethiopia (a word loaded with unfortunate connotations) is now out of the question. The two countries have gone their separate ways. Most strikingly, it is difficult to detect any desire for it even in Ethiopia: the impetus that drove the governments of both Haile-Selassie and Mengistu Haile-Maryam to regard Eritrea as an integral part of their national territory, sacrificing numberless human lives in the process, now appears to be entirely exhausted. Whereas the long independence war was fought, from an Ethiopian point of view, on the premise that Eritrea was part of Ethiopia, the war of 1998-2000 revealed a totally different perception, of Eritrea as the threatening "other". That sense of threat is now greatly diminished, since the war itself restored Ethiopian regional primacy, and the new drive for developmental statehood has reduced the relationship to peripheral status. And though the formal border between the two states remains open to question, as a result of the complacent mismanagement of the issue by the commission established to resolve it (Clapham, 
2009), there is no practicable alternative to the acceptance of the present line of control, as on the frontier between India and Pakistan in Kashmir, as the de facto frontier.

Given that the re-establishment of a working relationship with Ethiopia is central to the creation of a structure of government within Eritrea capable of recapturing the loyalties of its people (involving, notably, the demobilisation of much of a massive army in which young Eritreans are currently compelled to spend much of their lives), and the development of an Eritrean economy which must take advantage especially of trade with Ethiopia through the Red Sea ports of Assab and Massawa, this is a solution that any reforming government of Eritrea must be bound to accept. This will nonetheless present considerable difficulties for a new Eritrean leadership, not only because of the history of conflict between the two states, but because the balance of advantage has shifted so dramatically in Ethiopia's favor since Eritrea retreated into self-imposed isolation after its defeat in 2000. At the time of independence in 1991, the EPLF regarded itself as unquestionably the senior partner in its alliance with the Tigray People's Liberation Front (TPLF) to the south, which led the struggle against the Derg regime within Ethiopia, and then became the leading element within the EPRDF. Only this mindset can account for the catastrophic Eritrean decision to seize contested areas on the border in May 1998. Not only did the war that followed demonstrate Ethiopia's military superiority, but the subsequent fifteen years have been a period of dramatic economic growth in Ethiopia and of stagnation in Eritrea, while Ethiopia has also consolidated its position as the diplomatic hub of Africa, and also enjoys very positive relations both with the Western alliance and with China. Any arrangements that readmits Eritrea to the regional economy and diplomatic network will therefore be one which necessarily acknowledges Ethiopian superiority, and in which the country's bargaining position is extremely weak, with the issue of the border as a particularly sensitive one.

Beyond that, any narrative of Eritrean transformation must now look forward to a sense of what a small and ethnically and religiously diverse state in a perennially fractious part of the world might plausibly become, rather than constantly backwards to a sacred but effectively unusable past. In that context, Eritrea has a good deal going for it, especially in the presence of a very large diaspora, many of whose members possess the skills and the networks needed for the country's incorporation into a globalised social, economic and political space, and who at the same time display a remarkable level of identification with the country that they have fled. The country's strategic situation, historically a source of weakness that led to its conquest and exploitation not just by neighbours but by global powers, also gives it, properly managed, considerable potential advantages. It would be fascinating to speculate as to what Eritrea might have become, had it fallen into the hands of a ruler with the vision and intelligence of a Meles Zenawi, rather than those of an Isayas Afwerki. Though much valuable social capital has been frittered away in wars, domestic repression and a relentlessly inward-looking identity, enough should still remain, given the opportunity, to rescue the futures of such a courageous and enterprising people.

\section{The Somali and South Sudanese Impasses}

When it comes not just to 'Somalia', whatever that may be, but to the Somali peoples who constitute the third great element from which a transformed Horn of Africa would have to be constructed, the elements of continuity are clear, and the prospects for transformation correspondingly obscure. Somali politics resembles nothing so much as the sea: constantly changing, frequently violent, but fundamentally always the same. The dominant narrative here, matching the role of the state in Ethiopia and of the struggle in Eritrea, remains that of the clan - and indeed the sub-clan and sub-sub-clan, down through the multiple levels of Somali society's 
perennially fractious structures of patrilineal descent. Transformation in pastoralist societies is inherently more problematic than in peasant ones. Indeed, it is not clear that it has been successfully managed anywhere, other than through the displacement of pastoralism by alternative means of creating a livelihood, in ways that are hard to project for a region in which pastoralism remains by far the dominant mode of production. Somali politics can certainly be managed better, as for the most part been the case in Somaliland since its self-declared independence in 1991; or worse, as has likewise been the case in former Italian Somalia, not only since 1991 but for long before. Indeed, the range of variance across the five different territories-Djibouti, the former British Somaliland that has now asserted independent statehood as Somaliland, the Somali-inhabited areas of Ethiopia, former Italian Somalia, and north-east Kenya — between which Somalis have (with virtually no input of their own) historically been divided, provides intriguing insights into alternative models of management.

The most interesting of these is Somaliland, which has created a broadly stable and democratic state that has survived unrecognized for twenty-four years, albeit at a low level of development and state capacity. This has been brought about through a characteristically Somali process of discussion and negotiation, established in the first place through an open-ended meeting of elders from all of the clans within the territory, known in Somali as a guurti, which laid down the fundamental rules of the Somaliland political system, including a three-party system so designed as to discourage clan divisions and to promote power-sharing (Walls, 2009). It is not merely tragic but scandalous that this - by far the most successful of numerous attempts to manage the perennially fractious Somali political space - has failed to attract the external support lavished on endless provisional and transitional regimes in Mogadishu, with the result that Somaliland has been unable to benefitespecially in terms of economic development - to anything like the extent which it deserves from its political achievements. Somaliland certainly enjoys advantages derived from the robustness of its indigenous social structure, the common memory of suffering under the Siyad Barre regime before 1991, and the preponderance of the Isaaq clan grouping that provides an element of social and political stability. Each of the Somali territories has peculiarities of its own that prevent any straightforward replication between one and another, and in each of them, some way has to be found of juggling the politics of clan. But as to whether there is any way of managing Somali politics other than through constant balancing, bargaining, negotiation and renegotiation between entities defined essentially by descent, in a setting in which any conception of overall authority or legitimacy is at best extremely elusive, I remain sceptical.

A further element of regional destabilization is now provided by the collapse of South Sudan, only a few years after its independence, into a condition of statelessness akin to that of south-central Somalia. As in Somalia, too, managing this conflict is not merely a matter of stitching up some kind of elite accommodation between actors - call them "warlords" or what you will — whose entirely self-serving agendas are the most visible expression of crisis. The central problem is that there is no "state", in the sense of a structure of effective institutions, control over which might be negotiated; and what passes for the state is little more than the opportunity to appropriate the very large amounts of money that derive from the country's oil (de Waal, 2014). The most that can be said for the South Sudanese imbroglio is that it is at least relatively containable, its most important impact on the Horn being through the Gambella region of southwest Ethiopia.

\section{The Changing Regional Environment}

But when we turn from the individual states of the Horn to the wider regional picture, there has been a dramatic change from most of the last 50 years, from a highly conflictual region in which each major state has 
tried to destabilize its neighbors, to one with a much higher level of regional consensus. For this, we must thank, firstly, the end of the Cold War, which globalized regional conflicts in a way that was massively damaging for most of the region's people; and secondly, the abandonment of attempts by both Ethiopian and Sudanese states to impose their control on sections of their own then territories, Eritrea and South Sudan, that evidently resisted it, inducing each of them, in pursuit of their agendas for internal domination, to destabilize one another, through Sudanese support for separatists in Eritrea, and corresponding Ethiopian support for separatists in South Sudan. These two issues have now been resolved by Eritrean and South Sudanese independence, whatever the problems in each of the successor countries.

The most striking feature of engagement by regional states in both Somalia and South Sudan at the present time, by contrast, has been their overwhelming concern to resolve these problems, no matter how unsuccessful their attempts to do so, rather than using them to pursue their own rivalries with one another. The one evident 'spoiler' in regional peace processes, Eritrea, has been so weakened by the problems of its own internal governance, that it has in practice been obliged to withdraw from any significant engagement. Underlying this very welcome shift has been not only the ending or at least reduction of previous sources of regional tension, but much more positively, the articulation of a new narrative, through which to pursue a more consensual and collaborative vision for the region, in place of the rivalries of the past. This is the project of shared development, built principally on the model of the Ethiopian developmental state and extended to Ethiopia's neighbors, and the great symbol of this project is electrification. Added to this are integrated transport networks, with the still embryonic Lamu Port, South Sudan and Ethiopia Transport Corridor (LAPSSET) at their core, though the future of this project remains extremely uncertain, given the level of political instability in two of the areas, the Somali inhabited part of Kenya and South Sudan, through which its lines of communication would need to pass. Even the current level of collaboration over the Nile waters and the GERD between Ethiopia, Sudan and even Egypt is nonetheless already quite unprecedented (Goitom, 2014).

This narrative, however, is unequivocally one of Ethiopian hegemony, entrenching Ethiopia's role as the central and leading state of the region, and its realization depends on three key criteria. The first is that it requires the maintenance of a stable political settlement within Ethiopia, and even though the quasi-federal system put in place after 1991 has so far essentially held, this is always potentially problematic. Governing Ethiopia has never been easy, it cannot be achieved by top-down coercion, and it requires a capacity to maintain a place for all the major actors in the system which has only very partially been realized. The second is that it requires the acceptance of the other states within the region, and even though Ethiopia currently enjoys an exceptional level of regional influence, this is a situation that historically has seldom lasted for long. Apart from the continued hostility of Eritrea, which as already noted has little if any alternative to patching up its relations with its giant southern neighbor, the principal danger derives from the possibility of an al-Shabaab victory in Somalia, allied to the mobilization of Islamist movements within Ethiopia itself. The third is the need at least to contain, if not to resolve, the massive problems of governance in both Somalia and South Sudan.

\section{Conclusion}

In a superb recent study, Alex de Waal (2015) presents a cogently argued (and deeply depressing) picture of the Horn as a region driven by political entrepreneurs, concerned only to play the market in money and violence in such a way as to ensure their own profit and survival, in complete contempt for the welfare of the 
peoples whom they supposedly govern. Almost missing from this account, written essentially from the perspective of the region's peripheries, is nonetheless the view from the core, and notably Ethiopia. Central to the region's future, in a sense, is whether the corrosive mis-governance evident especially in Somalia and South Sudan will overwhelm the transformative agenda visible notably in Ethiopia, or whether a developing Ethiopia and, hopefully, a reconstructed Eritrea are capable of integrating the Horn in a way that benefits all of its peoples - including, indeed, its rulers. This would necessarily involve an element of highland hegemony, of a kind that has historically been problematic, and it would be naïve to suppose that it could be achieved without smart and at times coercive management. And while the values of the political entrepreneurs whose depredations de Waal so incisively exposes may be beyond plausible change, what "can" change is the setting within which these have to operate, and which in turn defines what constitutes "rational" behavior even from the perspective of the most ruthless. Important, too, is the constructive engagement — or very often, indeed, disengagement - of international actors whose misconceived (however well-meaning) intervention in regional conflicts has much more often than not been counter-productive, and this task has been made more complex by the appearance of new powers, including notably China.

But to return to the question with which this discussion started "Can the Horn Change?" the answer suggested here is therefore, perhaps surprisingly, Yes. This region does not "have" to remain locked in the interlinked regional and domestic conflicts that have defined it over most of the last 50 years. Some of these conflicts, notably in Somalia and South Sudan, are deeply intractable, and all that one can reasonably hope is that they may be isolated. Many of the region's problems, including governance issues within states - not least Ethiopia-will require very careful management. But on the whole, the prospects look better than at any time since, with the formation of the Organization of African Unity in Addis Ababa in 1963, Ethiopia managed the extraordinary feat not just of creating a union of the independent states of Africa, but of placing itself at the centre of it.

The Horn of Africa often appears to be an isolated part of the world, driven by its peculiar internal dynamics, and bending whatever influences impinge on it from outside to the demands of its own domestic and internal politics. Those who have studied it, whether from inside or outside the region itself, have readily taken on a similarly localized vision, and interpreted the twists and turns of its affairs essentially as the workings of its distinctive logics. It is all the more worth remembering, therefore, that many societies around the world have been transformed through processes of economic development, and of social and political change, into places whose people think and behave in ways inconceivable just a century ago. This is strikingly evident in many parts of Europe, now commemorating the centenary of the catastrophic outbreak of war in 1914, and the quarter-centenary of the fall of the Berlin wall in 1989, and the reunion of a continent that was brutally divided after 1945. The greater part of eastern Asia has seen an even more miraculous and more recent transformation, and parts at least of Latin America show signs of following it. Even some states in sub-Saharan Africa, long the developmental laggard of the international system, appear to be settling into a trajectory of steady economic growth, guided by governments elected by, and broadly accountable to, the people whom they govern. The Horn may well appear to be a laggard, even within Africa, but at the very least, these are possibilities that we should not exclude even for a region as distinctive as this, and we need to keep our own mental maps ready to find a place for them. 


\section{References}

Baxter, P. T. W, Hultin, J., \& Triulzi, A. (Eds). (1996). Being and becoming Oromo: Historical and anthropological enquiries. Uppsala: Nordiska Afrikainstitutet.

Bernal, V. (2013). Sacrificial citizenship: The Eritrean state and modes of belonging. University of Florida, 29th Gwendolen Carter Conference. Retrieved from http://africa.ufl.edu/files/carter2013program.pdf

Clapham, C. (1964). The birds of the Dahlac Archipelago. Ibis, 106, 376-388.

Clapham, C. (1988). Transformation and continuity in revolutionary Ethiopia. Cambridge: Cambridge University Press.

Clapham, C. (2009). Indigenous statehood and international law in Ethiopia and Eritrea. In A. De Guttry, H. H. G. Post and Venturini, G. (Eds.), The 1998-2000 War between Eritrea and Ethiopia: An international legal perspective (pp. 159-170). The Hague: TMC Asser Press.

Crisis Group. (2009). Ethiopia: ethnic federalism and its discontents. International Crisis Group, Africa Report No. 153. Retrieved from http://www.crisisgroup.org/ /media/Files/africa/horn-of-africa/ethiopia-eritrea/Ethiopia\%20Ethnic\%20Federalism\%20and\% 20Its\%20Discontents.pdf

de Waal, A. (2014). When kleptocracy becomes insolvent: Brute causes of the civil war in South Sudan. African Affairs, 113, 347-349.

de Waal, A. (2015). The real politics of the Horn of Africa: Money, war and the business of power. Cambridge: Polity Press.

Donham, D., \& James, W. (Eds.). (1986). The southern marches of imperial Ethiopia: Essays in history and social anthropology. Cambridge: Cambridge University Press.

Eritrea website. Retrieved from http://countrymeters.info/en/Eritrea

Fantini, E. (2015). Go Pente! The charismatic renewal of the evangelical movement in Ethiopia. In G. Prunier and E. Ficquet (Eds.), Understanding contemporary Ethiopia: Monarchy, revolution and the legacy of Meles Zenawi (pp. 123-146). London: Hurst.

Federal Democratic Republic of Ethiopia (FDRE). (1994). Constitution of the Federal Democratic Republic of Ethiopia. Addis Ababa: FDRE.

Feyissa, D. \& Hoehne, M. V. (Eds.). (2010). Borders \& borderlands as resources in the Horn of Africa. Woodbridge: James Currey. Ficquet, E. (2015). The Ethiopian Muslims: Historical processes and ongoing controversies. In G. Prunier and E. Ficquet (Eds.), Understanding contemporary Ethiopia: Monarchy, revolution and the legacy of Meles Zenawi (pp. 93-122). London: Hurst.

Gagliarodone, I. (forthcoming). Technology has politics: Information and communication technologies and development in Ethiopia. Cambridge: Cambridge University Press.

Gilkes, P. (2015). Elections and politics in Ethiopia, 2005-2010. In G. Prunier and E. Ficquet (Eds.), Understanding contemporary Ethiopia: Monarchy, revolution and the legacy of Meles Zenawi (pp. 313-331). London: Hurst.

Goitom, G. (2014). Ethiopia's Grand Renaissance Dam: Ending Africa's oldest geopolitical rivalry? Washington Quarterly, 37(2), 25-37.

Kibreab, G. (2013). The national service/Warsai-Yikealo Development Campaign and forced migration in post-independence Eritrea. Journal of Eastern African Studies, 7, 630-649.

Lefort, R. (2007). Powers-mengist - and peasants in rural Ethiopia: The May 2005 elections. Journal of Modern African Studies, $45,253-273$.

Lefort, R. (2010). Powers — mengist - and peasants in rural Ethiopia: The post-2005 interlude. Journal of Modern African Studies, $48,435-460$

Lefort, R. (2012). Free market economy, "developmental state" and party-state hegemony in Ethiopia: The case of the "model farmers". Journal of Modern African Studies, 50, 681-706.

Levine, D. N. (1965). Wax \& Gold: Tradition and innovation in Ethiopian culture. Chicago, IL: University of Chicago Press.

Hassen, M. (1990). The Oromo of Ethiopia: A history 1570-1860. Cambridge: Cambridge University Press.

Østebø, T., \& Desplat, P. (2013). (Eds.). Muslim Ethiopia: The Christian legacy, identity politics and Islamic reformism. New York: Palgrave Macmillan.

UNHCR website. Retrieved from http://www.unhcr.org/cgi-bin/texis/vtx/page?page=49e4838e6\&submit=GO

Walls, M. (2009). The emergence of a Somali state: Building peace from civil war in Somaliland. African Affairs, 108, $371-389$.

World Bank website1, Mobile cellular subscriptions (per 100 people). Retrieved from http://data.worldbank.org/indicator/IT.CEL.SETS.P2

World Bank website2, http://databank.worldbank.org/data/views/reports/tableview.aspx 